Original Articles

20. Veitch MGK, Owen LR. Rise in invasive serogroup W meningococcal disease in Australia 2013-2015. Communicable Diseases Intelligence. 2016; 40 (4): 451-453.

21. Frank T, Hong E, Mbecko JR et al. Emergence of Neisseria meningitidis Serogroup W, Central African Republic, 2015-2016. Emerging Infectious Diseases. 2018; 24 (11): 2080-2083.

\section{Об авторах}

- Мария Игоревна Грицай - аспирант лаборатории эпидемиологии менингококковой инфекции и гнойных бактериальных менингитов ЦНИИ эпнгококковой инфекции и гнойных бактериальных менингитов ЦНИИ maria-griz@mail.ru.

- Мария Александровна Королёва - к. М. Н., старший научный сотрудник лаборатории эпидемиологии менингококковой инфекции и гнойных бактериальных менингитов ЦНИИ эпидемиологии. 111123, Москва ул. Новогиреевская, За. +7 (916) 3638248, korolevamaria389@gmail.com. ORCID: https://orcid.org/0000-0002-2714-1191.

- Нона Николаевна Фомкина - начальник отдела эпидемиологического надзора Управления Роспотребнадзора по городу Москве 129626, г.Москва, Графский переулок, д.4, корп. 2.+7 (903) 6864813, fomkina.nona@mail.ru.

- Ирина Станиславовна Королева - д. м. н., заведующая лабораторией эпидемиологии менингококковой инфекции и бактериальных менинги тов ЦНИИ эпидемиологии. 111123, Москва, ул. Новогиреевская, 3а. irinakorol@yandex.ru. ORCID: https://orcid.org/ 0000-0003-0578-146X.

Поступила: 13.02.2020. Принята к печати: 14.04.2020.

Контент доступен под лицензией СС ВY 4.0 .

\section{About the Authors}

Maria I. Gritsay- postgraduate student at the Laboratory of the Epidemiology of Meningococcal Infection and Bacterial Meningitis of the Central Research Institute of Epidemiology. st. Novogireevskaya, 3a, Moscow111123, Russia.+7 (910)1451098. maria-griz@mail.ru.

- Maria A. Koroleva - Cand. Sci. (Med.), senior researcher at the Laboratory of the Epidemiology of Meningococcal Infection and Bacterial Meningitis of the Central Research Institute of Epidemiology. st. Novogireevskaya, 3a, Moscow 111123, Russia.+7 (916) 3638248, korolevamaria389@gmail.com. ORCID https://orcid.org/0000-0002-2714-1191.

- Nona N. Fomkina - Head of the Department of Epidemiological Surveillance of the Office of Rospotrebnadzor in Moscow, Grafsky Lane, 4, building. 2, Moscow 129626, , Russia. +7 (903) 6864813, fomkina.nona@mail.ru.

- Irina S. Koroleva - Dr. Sci. (Med.), Head of the Laboratory of the Epidemiology of Meningococcal Infection and Bacterial Meningitis of the Central Research Institute of Epidemiology. st. Novogireevskaya, 3a, Moscow111123, Russia. irina-korol@yandex.ru. ORCID: https://orcid.org/ 0000-0003-0578146X.

Received: 13.02.2020 Accepted: 14.04.2020.

Creative Commons Attribution CC BY 4.0

\title{
ИНФОРМАЦИЯ ВОЗ
}

\section{В03 предупреждает: если приостановить оказание важных медицинских услуг,}

\section{достигнутые успехи вакцинации могут уйти в прошлое}

В преддверии Всемирной недели иммунизации (2430 апреля) В03 заявила, что без оказания услуг в области иммунизации из-за пандемии COVID-19 будет трудно предотвратить угрозу нового витка распространения болезней, предупреждаемых с помощью безопасных и эффективных вакцин.

Приостановка оказания услуг в области вакцинации даже на короткий промежуток времени в связи с чрезвычайной ситуацией повышает риск возникновения вспышек болезней, предупреждаемых с помощью вакцин, таких как корь или полиомиелит. Необходимо, чтобы предоставление важных услуг в области здравоохранения, таких как иммунизация, не прекращалось даже в период чрезвычайных ситуаций, о чем наглядно свидетельствует пример Демократической Республики Конго, в которой от смертоносной вспышки кори, разразившейся в прошлом году на фоне крупнейшей вспышки Эболы, умерли более 6000 человек. Кроме того, вспышки новых болезней способны вызвать перегрузку систем здравоохранения, которые заняты ликвидацией последствий COVID-19.

Совместно с партнерами из разных стран мира ВОЗ работает над ускорением исследований и разработок безопасной и эффективной вакцины, а также обеспечением равноправного доступа к ней для миллиардов нуждающихся людей.

Впрочем, прежде чем вакцина будет создана, должно пройти определенное время, даже при высоких темпах работы. Чтобы обезопасить себя от заболеваний, в том числе тех, против которых существуют взрослые и детские вакцины, в настоящее время необходимо соблюдение мер профилактики.

\section{Многие люди по-прежнему не имеют доступа} к преимуществам вакцинации

До начала пандемии COVID-19 в мире были достигнуты значительные успехи в области вакцинации детей. В 2018 г. 86\% детей в возрасте до пяти лет во всем мире получили три прививки против дифтерии, столбняка и коклюша (КДСЗ) и одну против кори, тогда как в 2000 г. - 72\%, а в 1980 г. - 20\%. Число случаев паралича вследствие полиомиелита у детей удалось сократить на 99,9\% в глобальном масштабе. Тем не менее, глобальный охват иммунизацией все еще далек от уровня в 95\%, необходимого для полноценной защиты общества от вспышек этой болезни, предупреждаемой с помощью вакцин.

В 2018 г. около 20 млн детей во всем мире, то есть больше 1 из 10, не были охвачены жизненно важными прививками против кори, дифтерии и столбняка. Порядка 13 млн детей не были вакцинированы, что создает риск заболевания и смерти как для них самих, так и для окружающих их людей. Большинство этих детей проживают в странах со слабыми системами здравоохранения, и это, в свою очередь, еще больше ограничивает их доступ к основным услугам здравоохранения в случае заболевания.

Корь по-прежнему представляет угрозу, в особенности на фоне слабого охвата вакцинацией. По имеющимся рассче там, в 2019 г. корью могли быть заражены порядка 800000 людей во всем мире. Вызывает все больше опасений риск возникновения нового витка заболевания в 2020 г., в особенности в случае отсрочки или временной приостановки плановой иммунизации с последующим снижением уровня охвата.

Как свидетельствует опыт реагирования на чрезвычайные ситуации в предыдущие годы, например на вспышку полиомиелита в Сирии в 2013 г., вспышки полиомиелита, дифтерии и желтой лихорадки вызывают не меньшую обеспокоенность, особенно в странах, в которых оперативное развертывание мер для ликвидации новой вспышки затруднено.

Постоянное оказание услуг в области иммунизации во время пандемии COVID-19

С тем чтобы свести к минимуму количество вспышек заболеваний и спасти жизни, одновременно с ликвидацией последствий COVID-19 страны должны незамедлительно предпринять шаги для обеспечения бесперебойного оказания услуг по иммунизации населения. Имеется в виду, в том числе, организация наверстывающих мероприятий по иммунизации в районах, в которых оказание услуг было приостановлено, с задействованием надежных систем снабжения и эпиднадзора, а также с привлечением подготовленных медико санитарных работников.

В новом документе ВО3 в отношении иммунизации и COVID-19 правительствам стран рекомендуется при отсутствии в данный момент вспышки болезни, предупреждаемой с помощью вакцин, временно приостановить кампании по профилактической вакцинации. Тем не менее, в нем содержится призыв к тому, чтобы в приоритетном порядке решить вопрос о непрерывной плановой иммунизации детей в рамках оказания жизненно важных услуг, а также взрослых, например в случае вакцинации от гриппа людей, подвергающихся наи большему риску. При вынужденной необходимости приостановить услуги в области иммунизации следует как можно раньше организовать наверстывающие мероприятия и уделить приори тетное внимание людям, подвергающимся наибольшему риску.

Источник: https://www.who.int/news-room/detail/23-042020-hard-fought-gains-in-immunization-coverage-at-risk-withoutcritical-health-services-warns-who 